\title{
Tohum Diş Ticaretinde Rekabet Gücünün Analizi ve Değerlendirilmesi
}

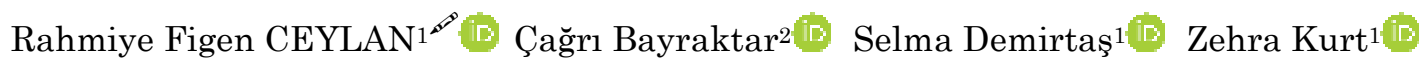 \\ ${ }^{1}$ Akdeniz Üniversitesi Ziraat Fakültesi Tarım Ekonomisi Bölümü, ${ }^{2}$ T.C. Sanayi ve Teknoloji Bakanlığı, Antalya İl Müdürlüğü, Antalya \\ $\bowtie$ : ceylan.figen@gmail.com
}

\section{ÖZET}

Günümüzün dış ticarete açık dünyasında tarımsal faaliyetlerde iç yeterlilik hem üretim hem de tüketim aşamalarında ticaret avantajlarının elde edilmesi ile mümkündür. Ancak, sağlık duyarlılıkları ile birlikte verim artışının da sağlanması gereken mevcut bitkisel üretim düzeninde, tarımsal girdilerde dışa bağımlılığın azaltılmasına özel önem verilmesi gerekmektedir. Önemli bir üretici ülke olan Türkiye'nin tohum dış ticaret açı̆̆ı 2000'li yılların başından beri azalmaktadır. 2015 yılında Türkiye'nin tohumluk ihracatının ithalatı karşılama oranı \% 59 iken, 2016 yılında bu oran daha da yükselmiştir. Bu değişimin, ihracat yapılan ülkelere ve zamana göre analiz edilmesi istenmiştir. Türkiye'nin on ticaret ortağı ülkeye olan tohumluk ihracatı 2000-2017 yılları için oransal değişimler aracılığıyla incelenmiştir. Bu değerlendirme sonrasında, temel ticaret ortaklarından Irak'ın veri yetersizliği nedeniyle dışarıda bırakılmasının ardından, Türkiye'nin 2000-2015 yılları arasında elde ettiği tohum ihracat geliri panel veri analizi aracılığıyla 9 ithalatçı ülke için analiz edilmiştir. Uygulanan yer çekimi modeli analiz sonuçlarına göre, ithalatçı ülkenin kişi başı milli gelir artışı, bu ülkenin nüfus artışı ve Türk Lirası'nın Dolar'a karşı değer kaybı tohum ihracat gelirini artıran etkenler olarak belirmiştir. Ayrıca, Türkiye'de tohum üretim artışı ve ithalatçı ülkenin Avrupa Birliği üyesi olma durumu, Türk tohum ihracat gelirinin dönemler arası farkını pozitif yönde etkilemektedir. Bu hususta önceliğin üretim artışına verilmesi ve tohum üreticilerinin daha fazla desteklenmesine yönelik çalışmalara gerek duyulduğunu belirtmekte fayda vardır.

\section{Analysis of Turkey's Competitiveness in Seed Foreign Trade}

\section{ABSTRACT}

Internal competence in agricultural activities in today's outdoor trade open world is possible both by the advantages of trade in both production and consumption stages. There is a need in order to plan the future planning of the seed production and foreign trade that can adapt to the developing production technologies and to bring high efficiency and to direct the investments towards the sector. Turkey's seed foreign trade deficit decreased since the early $2000 \mathrm{~s}$, which is one of the important producer countries. Turkey's seed import coverage ratio of exports in 2015 was 59\%, this rate is increased further in 2016 . It was intended to analyse this change due to export destinations and time. Turkey's seed export to trade partner countries was investigated with rational changes for 2000-2017 years. After this evaluation, following exclusion of Iraq, which is one of the main trade partners, due to data availability, Turkey's seed export value for 2000-2015 was analysed for 9 importer countries with panel data analysis. Applied gravity model analysis results indicated that rising in importer country's per capita income and population and devaluation of Turkish Lira against Dollar appeared as factors rising seed export revenue. In addition, the rise in seed production in Turkey, and European Union membership status of importer country affected
Makale Tarihçesi

Geliş : 21.10.2018

Kabul : 27.12.2018

Anahtar Kelimeler

Türkiye,

Tohum,

Diş Ticaret,

Ihracat Geliri,

Panel Veri Analizi,

Yer Çekimi Modeli

Araştırma Makalesi

Article History

Received : 21.10.2018

Accepted : 27.12.2018

\author{
Keywords \\ Turkey, \\ Seed, \\ Foreign Trade, \\ Export Revenue, \\ Panel Data Analysis, \\ Gravity Model
}

\section{Research Article}


inter-period difference of Turkish seed export revenue in a positive direction.

To cite: Ceylan RF, Bayraktar Ç, Demirtaş S, Kurt Z 2018. Tohum Dış Ticaretinde Rekabet Gücünün Analizi ve Değerlendirilmesi. KSÜ Tar Doğa Derg 21(Özel Sayı) : 22-34, DOI : 10.18016/ ksutarimdoga.vi.472886

\section{GİRİŞ}

Tarım sektörü; beslenme için gerekli bitkisel ve hayvansal gıda maddeleri ihtiyacının giderilmesi ile birlikte, endüstriyel üretim için gerekli ham maddenin sağlanması yoluyla ülke ekonomisine kazandıracağı katma değer açısından oldukça önemlidir. Gıda tüketimi, artan dünya nüfusu, yükselen hayat standartları ve değişen tüketim alışkanlıkları gibi sebeplerle, her geçen gün artmaktadır. Giderek artan gıda ihtiyacını karşılamada yeni yöntem ve teknolojilerin kullanılmasıyla tarımsal üretimde verimliliğin arttırılması kaçınılmaz hale gelmiştir. Yapılan Ar-Ge çalışmaları sonucu elde edilen yeni ve üstün çeşitler sayesinde geleneksel metotlara ve eski çeşitlere nazaran önemli verim artışları sağlanabilmektedir. Tohumculuk sektörü hem yarattığı yüksek katma değer hem de stratejik konumu sebebiyle, ülke ekonomisi için büyük öneme sahiptir. Tohum konusunda gerçekleştirilen Ar-Ge çalışmaları, tarım işletmelerinin yönetim yapılarında meydana gelen değişiklikler, tohum teknolojisinde öne çıkan küresel dev firmaların sektörü sürükleyen yenilikleri gibi birçok unsur nedeniyle sektörün rekabetçi yapısı son yıllarda köklü değişimlere uğramıştır.

Türkiye'nin dünya tohumluk üretim ve ticaretinden aldığı pay sahip olduğu elverişli ekolojik koşullara rağmen beklentilerin oldukça altındadır. Tohumculuk sektörünün kontrollü gelişiminin ön plana çıkması 1963 yılında uygulamaya koyulan 308 sayılı Tohumculuk Tescil, Kontrol ve Sertifikasyonu Hakkında Kanun ile gerçekleşmiştir (Altındal ve Akgün, 2007). İç ihtiyacı karşılama ve verim artışı hedefleriyle 1983 yılında özel sektöre kontrollü tohum üretimi izni verilmiş, 1984 yılında ise sübvansiyonlu tohum ithalatının önü açılmıştır (Gençtan ve ark., 2007; Altındal ve Akgün, 2007; Sahin ve ark. ). Bu dışa açılım sürecinde üreticilerin fiyat belirlemesi mümkün kılınmıştır. Bu durum ithalatın gelişmesinin yolunu açmış, iç ihtiyaç fazlası tohum üretimi ise özel sektörün inisiyatifine bırakılmıştır (Yağdı ve ark., 2010).

Sektörün bağımsız fiyat belirlemesinin yanı sıra, ihracata konu olan tohumluklar da dahil olmak üzere, ürünlerin tabi olduğu yüksek Katma Değer Vergisi (KDV) oranları ihracatın gelişmesinin önündeki engellerden biri olarak görülmüştür (Elçi, 2000). Üretici ve ihracatçıların üzerindeki bu yükün azaltılması için, 1998 yılında tohumluk ihracatında en büyük paya sahip olan tarla bitkileri tohumluğu için öngörülen düzenleme ile kanun ile tüm tohumlukların tabi bulunduğu KDV oranı \% 15 'ten $\%$ 8' e düşürülmüştür. $\quad \mathrm{Bu}$ uygulama 2003 yllında uygulamaya koyulan kanun ile tüm tohumluklar için genişletilmiştir. $\mathrm{Bu}$ değişikliğin ihracat rakamlarına ve ihracatın ithalatı karşlama oranlarına olumlu etkileri olduğu düşünülmekle birlikte, oranların daha da aşağı çekilmesi gerektiği öne sürülmektedir (Elçi, 2000)

Dünya tohumluk sektörü Ar-Ge çalışmaları ve üretim teşvikleri ile giderek gelişirken, Türkiye'nin bu sektör içindeki payı değişmektedir. Örneğin, dünyada toplam tohumluk ihracat değeri 2007 yılında 36.5 milyar Dolar iken, 2012'de bu değer 45 milyar Dolar'a yükselmiştir (Yağdı, ve ark., 2010; Yağdı ve ark., 2015). Bu ihracat değerleri, TÜIKK resmi verilerine göre, Türkiye için sırasıyla 58 ve 116 milyon Dolar' dır. Bu değerler, potansiyeline kıyasla Türkiye'nin ihracat gücünün oldukça zayıf olduğunu göstermektedir. Türkiye'nin özellikle hibrit sebze tohumculuğunda önemli ilerlemeler kaydettiği belirtilmelidir. Üretim miktarı açısından başta yağlı tohumlar olmak üzere, temel hububat tohumlarında da ihracatın ithalatın çok önünde olduğu Şahin ve arkadaşlarının (2013) gerçekleştirdiği 2002-2011 yılları arasını kapsayan oransal çalışmada ortaya koyulmuştur. Çalışmamız üretim veya ticaret rakamlarını değerlendirmekten ziyade, Türkiye'nin tohumluk ihracatındaki gelişme potansiyelini ana ticaret ortaklarıyla karşlaştırmalı olarak değerlendirme amacıyla gerçekleştirilmiştir.

$\mathrm{Bu}$ çalışma kapsamında Türkiye'nin tohum dış ticaretinde yıllara bağlı değişimin incelenmesi amaçlanmıştır. Dış ticaretin iki taraflı değerlendirilmesi ve potansiyel gelişme alanlarının belirlenmesinde en sık kullanılan yöntemlerden birisi Gravity ya da yer çekimi modelidir. Bu model, çift taraflı ticarette ülkelerin genel ekonomik büyüklüğü, karşı karşıya kaldıkları dönemsel değişimler ve ticaretin maliyetlerini esas alarak mevcut ve beklenen ticaret düzeyinin tahminine olanak sağlamaktadır (Disdier ve Marett, 2010). Bu model, Anderson (1979)'un teorik temellerini ortaya koymasinın üzerinden özel uygulamalarla geliştirilmiştir (Deardoff, 1998; Anderson ve van Wincoop, 2003). Yer çekimi modeli, dış ticareti açıklamada çok sayıda çalışmada kullanılmış ve istatistiksel geçerliliği ortaya koyulmuştur (Bacchetta ve van Wincoop, 2000; Cho, Sheldon, ve McCorriston, 2002; Hilbun, 2006). Model ticaret birliklerinin etkilerinin ölçülmesi ve olası birlikteliklerin hem birlik hem de üye ülke ticaret hacmi üzerine etkilerinin değerlendirilmesi amacıyla da sıklıkla kullanılmıştır (Ahcar ve Siroën, 2017; Kabir ve Salim, 2010). 
$\mathrm{Bu}$ çalışmada tarım sektörünün girdi bileşenleri arasında giderek daha fazla önem kazanan tohum dış ticaretinde Türkiye'nin ve ticaret ortağ ülkelerin ekonomik göstergelerden etkilenme düzeyi incelenmiştir. $\mathrm{Bu}$ inceleme kapsaminda Türkiye'nin tohum ticaretinde öne çıkan on ülke ile ticaretindeki zamana bağlı değişimler 2000-2017 yılları arasındaki verilerle değerlendirilmiş, bu ticaret ortaklarından dokuzuna yapılan ihracatın zamana ve ülkelere bağlı değişimi ise 2000-2015 dönemi için analiz edilmiştir.

Türkiye'nin temel tohum ticareti ortakları 10 ülke olarak belirtilmiş olmakla birlikte, betimleyici değerlendirmelerin ardından sosyo-politik gelişmeler nedeniyle Irak için verilerin yetersiz olduğu anlaşılmış ve panele dahil edilecek olan ülke sayısı 9'a indirilmiştir. Buna göre, panelimiz 9 ülke için 16 yıldan 144 verilik bir setten oluşmaktadır. Bu şekilde gerçekleştirilen panel veri analizi esasen ekonomik göstergeler, ekonomik ve politik birliklerin ticarete etkisi ile birlikte, ticaret ortakları arasındaki uzaklık özelinde sayısallaştırılan nakliye masraflarının etkisinin de incelenmesini hedeflemiştir.

\section{MATERYAL ve METOT}

\section{Materyal}

Çalışmamız ile ilgili ikincil veriler, Türkiye Tohumcular Birliği’ne (TÜRKTOB) bağll alt birliklerden alınmıştır.

Elde edilen yılllı veriler doğrultusunda Türkiye'nin 10 ülke ile olan tohum diş ticaret (ithalat ve ihracat) ilişkileri değerlendirilmiştir. Buna göre, çalışmamız kapsamında 2000-2017 yılları arasında Türkiye'nin dış ticaret değişimi, ticaret hacminin en yüksek olduğu aşağıdaki ülkelere ilişkin ikincil verilerden istifade edilmiştir. Ayrıca, analiz sürecinde kullanılan makroekonomik göstergeler TÜİK ve EUROSTAT gibi istatistiksel veri tabanlarından elde edilmiştir (Anonim, 2013, 2014, 2015a-2015e).

\section{Metot}

Çalışmamızda ürüne özel yer çekimi modeli kullanılmıştır. Bu yöntemde, bir ülkenin, ticaret ortağı ülkeye gerçekleştirdiği ihracat miktarı, her iki ülkenin milli gelir ve nüfusu ile iki ülkedeki ilgili ürün üretim miktarı, döviz kurları aracılığıyla tahmin edilmekte, bu tahminde ticaret masrafları ülkeler arası mesafe ile ölçülmektedir. $\mathrm{Bu}$ çalışmaları esas alarak kurulan öncül denklem aşağıdaki gibidir (Karamera ve ark., 2011; Kao, ve ark., 1994).

$X_{i j}=B Y_{i}^{\beta 1} Y_{j}^{\beta 2} d_{i j}^{\beta 3} N_{i}^{\beta 4} N_{j}^{\beta 5} \operatorname{Pr}_{i}^{\beta 6} \operatorname{Pr}_{j}^{\beta 7} E_{i j}^{\beta 8} e_{i j} \quad i=$

$1, \ldots \ldots, N$ ve $j=1, \ldots \ldots ., N$

Bu denklem sisteminde;

$\mathbf{X}_{\mathrm{ij}}=$ Ülke i'nin ülke j’ye ihraç ettiği ürün miktarı

$\mathbf{Y}_{\mathbf{i}}=\mathrm{i}$ ülkesinin kişi başı milli geliri (ihracatçı ülke)

$\mathbf{Y}_{\mathbf{j}}=\mathrm{j}$ ülkesinin kişi başı milli geliri (ithalatçı ülke) $\mathbf{d}_{\mathrm{ij}}=$ İki ülkenin ticari merkezleri arasındaki uzaklık $(\mathrm{km})$ - nakliye masrafları göstergesi olarak

$\mathbf{N}_{\mathbf{i}}=$ i ülkesinin nüfusu (ihracatçı ülke)

$\mathbf{N}_{\mathbf{j}}=\mathrm{j}$ ülkesinin nüfusu (ithalatçı ülke)

$\mathbf{P r}_{\mathbf{i}}=\mathrm{i}$ ülkesinin kişi başı üretim- tohumluk (ihracatçı ülke)

$\mathbf{P r}_{\mathbf{j}}=\mathrm{j}$ ülkesinin kişi başı üretim- tohumluk (ithalatçı ülke)

$\mathbf{E x}_{\mathbf{i j}}=\mathrm{i}$ ve $\mathrm{j}$ ülkelerinin Dolar'a endeksli döviz sepeti

$\mathbf{e}_{\mathbf{i j}}=$ rastlantisal hata

$\mathrm{Bu}$ modelden hareketle, çalışmada uygulanan başlangıç modeli aşağıdaki gibidir.

$$
X_{i j}=\beta_{1} Y_{i}+\beta_{2} Y_{J}+\beta_{3} E X C_{\mathrm{i}}+\beta_{4} E X C_{J}+\beta_{5} Q_{i}+
$$

$\beta_{6} N_{J}+\beta_{7} d_{i j}+\beta_{8} A B_{J}+\varepsilon_{i j}(2)$

$\boldsymbol{X}_{\boldsymbol{i}}=$ Türkiye'nin 9 ticaret ortağ ülke ile 2000-2015 yılları arasında gerçekleşen ihracatının değeri (milyon Dolar)

$\boldsymbol{Y}_{\boldsymbol{i}}=$ Türkiye'nin 2000-2015 yılları arasındaki Kişi Başı Milli Geliri (Dolar)

$\boldsymbol{Y}_{\boldsymbol{j}}=$ Ticaret ortağ 1 ülkenin $\quad 2000-2015$ ylları arasındaki Kişi Başı Milli Geliri (Dolar)

$\boldsymbol{E X C}_{\boldsymbol{i}}=$ Türk Lirası'nın Dolar cinsinden değeri (2000-2015)

$\boldsymbol{E X}_{\boldsymbol{j}}=$ Ticaret ortağ $\breve{g}_{1}$ ülkenin yerel para biriminin Dolar cinsinden değeri (2000-2015)

$\boldsymbol{Q}_{\boldsymbol{i}}=$ Türkiye'de 2000-2015 yılları arasında üretilen toplam tohumluk miktarı (ton)

$\boldsymbol{N}_{\boldsymbol{j}}=$ Türkiye'nin 2000-2015 yılları arasında ihracat yaptığı ülkelerin nüfusu

$\boldsymbol{d}_{i j}=$ Türkiye'nin $\quad 2000-2015$ yılları arasında ihracat yaptığı ülkelerin ticari başkenti ile İstanbul arasındaki mesafe $(\mathrm{km})$

$\boldsymbol{A B}_{\boldsymbol{j}}=$ Türkiye'nin 2000-2015 yılları arasında ihracat yaptığı ülkenin $\mathrm{AB}$ üyesi olup olmadığını gösteren kukla değişken (üye ise: 1; değilse: 0)

$\boldsymbol{e}_{\boldsymbol{i j}}=$ Panel veri analizine göre yatay kesit ve zaman unsurları değerlendirilecek olan hata terimi

Çalışmanın uygulamasında panel veri analizinde üç yöntem kullanılmaktadır (Arellano, 2003). Bu yöntemler Birleştirilmiş Panel En Küçük Kareler Tahmini, Sabit Etkiler Tahmini ile Tesadüfi Etkiler Tahmini' dir. Analizin zamana bağlı tahmini ile ilgili karar verilerin eş-bütünleşme düzeyine bakılarak verilirken, yatay kesit birimlerinin tahmindeki belirleyiciliği bağımlılık testleri ile ölçülmektedir.

$\mathrm{Bu}$ çalışmada zamana bağlı eş-bütünleşme testi için öncelikle derlenen ikincil verilerin zamana göre değişiminin birim kök testleri ile ölçülmesi gerekmektedir. Bu aşamada veri seti 9 yatay kesit ve 16 zaman bileşeninden oluştuğu ve dengeli olmadığ için Levin-Li-Chu panel birim kök testi kullanılmıştır 
(Levin ve Lin, 1992, 1993; Levin, Lin ve Chu, 2002). Bu testin hipotezi veri setinin farklı yatay kesitler göz önüne alınarak birim köke sahip olduğudur. Hipotezin istatistiksel olarak reddedilmesi, panel veri setinin yatay kesite, mevcut araştırmada ticaret ortağ ülkelere, göre zamana bağlı olarak durağan olduğunu ve eş-bütünleşmeye gerek olmayacağını gösterecektir. Verilerin zamana bağlı birim kökünün varlığı tespit edilirse, bu zaman etkisinin eş-bütünleşme yoluyla ortadan kalkıp kalkmayacağına bakılması gerekmektedir. $\mathrm{Bu}$ değerlendirme için Pedroni'nin (1999) geliştirdiği panel eş-bütünleşme testi kullanılmaktadır. Bu testin hipotezi eş-bütünleşme ile tahminin gerekmediği ve verilerin düzeyde tahmin edilebileceği varsayımına sahiptir.

Zamana bağlı varyasyonun incelenmesi ile birlikte yatay kesit bağımlılığının tespiti için de alternatif test yöntemleri bulunmaktadır. Veri setinin birleştirilmiş panel olarak mı yoksa zaman ve yatay kesit etkisinin hata terimi içerisine gizlendiği tesadüfi etkiler modeline göre mi tahmin edileceği kararı Breusch ve Godfrey Lagrange çarpanı testi ile verilmektedir (Breusch-Pagan, 1979; Godfrey 1978; Akıncı ve ark,. 2013). Bu test için hipotez zaman ve yatay kesit unsurlarının tahminde etkisinin olmadığını öne sürmektedir. Tesadüfi etkiler ile yatay kesit ve zaman unsurlarının tahmin denklemine rastlantısal hata haricinde tahmin edilen değişkenler olarak eklenmesine karşllık gelen sabit etkiler modelinin tercihine ise Hausman Belirleme testi ile bakılmaktadır (Baltagi, 2005). Hausman belirleme testinin sıfır hipotezi tahminin tesadüfi etkilere göre yapılabileceğini öne sürmektedir. Eğer hipotez istatistiksel olarak reddedilebilirse, tahmin sabit etkilere göre yapılabilecek ve koşul değişkenler doğrudan tahmin denkleminden ayrlabilecektir (Akıncı ve ark., 2013). Ayrıca, E-views istatistik programında sabit etkiler ve tesadüfi etkiler tercihini belirleyen Breusch ve Godfrey Lagrange çarpanı testini değerlendirmek için Olabilirlik Oranı (Likelihood Ratio) testi uygulanmaktadır. $\mathrm{F}$ ve $\mathrm{X}^{2}$ dağılımına sahip iki farklı istatistik üreten Olabilirlik Oranı testinin hipotezi, modelin birleştirilmiş model ile tahmin edilebileceği varsayımına dayanmaktadır. $\mathrm{Bu}$ test, birleştirilmiş ve sabit etkiler tahmini arasındaki tercihi sunmaktadır (Baltagi 2005). Bu çalışmada Hausman yatay kesit testi ve Olabilirlik Oranı testleri sabit-etkiler-tesadüfi etkiler tercihi için kullanılmış, birleştirilmiş panel tahmini değerlendirmesi uyum iyiliği ve otokorelasyon özellikleri göz önünde bulundurularak yapılmıştır.

Çalışma kapsamında, analitik tahmin bulguları öncesinde Türkiye tohum piyasasındaki gelişmeler veriler aracılığıyla değerlendirilmiştir.

\section{BULGULAR ve TARTIŞMA}

Türkiye'nin Tohumluk İhracat ve İthalatına İlişkin Genel Değerlendirme

Şekil 1'de 2000-2017 yllında Türkiye'nin toplam ihracat ve ithalat değişimi milyon Dolar cinsinden gösterilmektedir. 2000 yılında yaklaşık 23 milyon Dolar olan toplam tohum ihracatı, 2017 yılında yaklaşık 130 milyon Dolar'a yükselerek 6 katlık bir artış göstermiştir. Zaman serisine göre düzenli bir artış izlenirken, ihracat miktarında 2015 yılında keskin bir düşüş görülmektedir. İhracattaki bu düşüşün nedeni TÜRKTOB tarafından ticarette rekabet halinde bulunulan ülkelerdeki tohum çeşitliliği artışına doğrudan adapte olunamaması olarak belirtilmiştir.

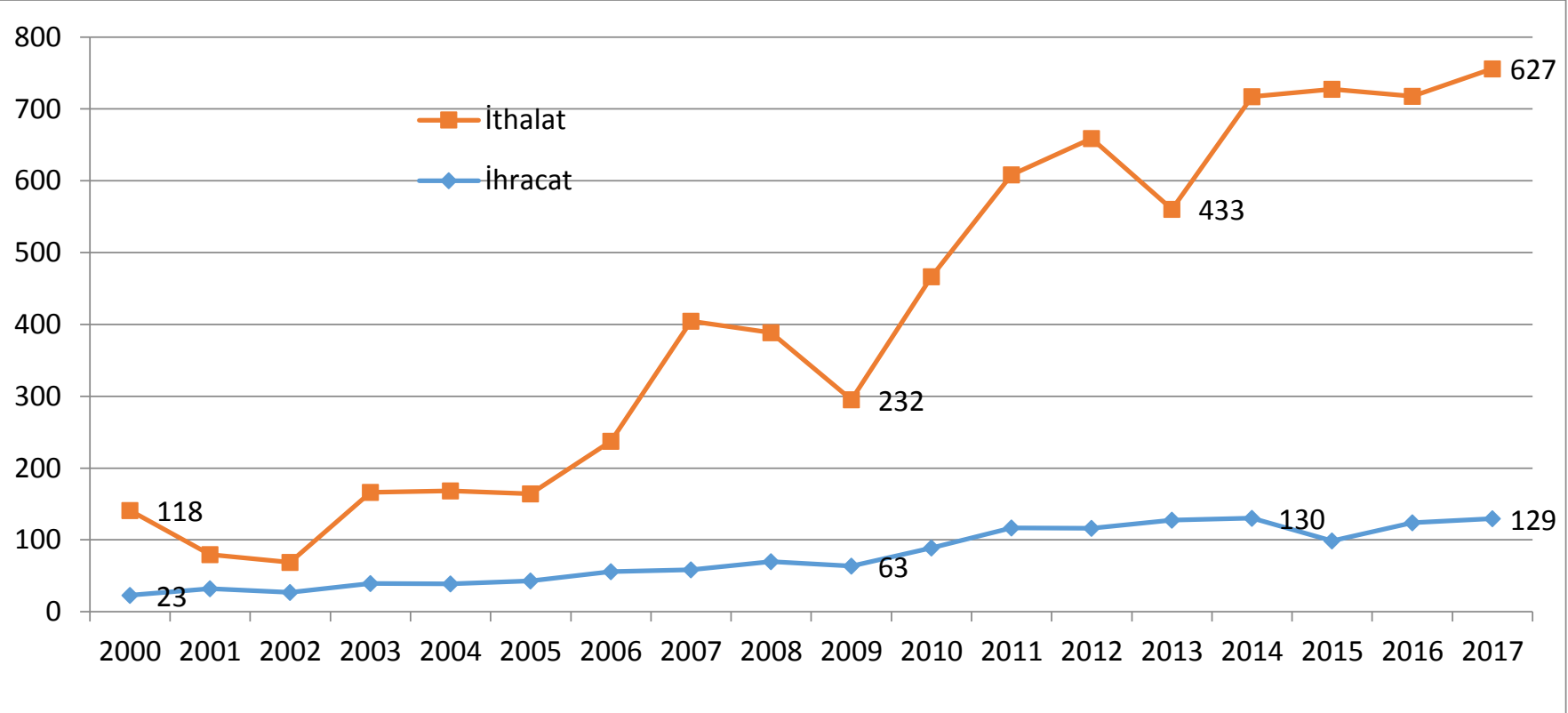

Şekil 1. Türkiye Tohum İhracat ve İthalat Geliri; 2000-2017 (Milyon Dolar) 
2015 yılında \% 70'e düşen ihracatın ithalatı karşılama oranı, 2016'da artan yatırımlarla \%86'ya yükselmiştir (Anonim, 2017). Bu daralmanın nedenlerinden bir diğeri ise ana ihracat ortaklarından Rusya Federasyonu'nda gerçekleşen Ruble devalüasyonu nedeniyle bu ülkeye yapılan ihracatın 2014'te 27.8 milyon Dolar'dan 2015 yllında 10 milyon Dolar'a düşmesidir (Anonim, 2016). Ayrıca, bu 17 yllın ihracat ortalaması 76.78 milyon Dolar olup; 2010 yılı itibariyle ihracat miktarı bu ortalamanın hep üzerinde olmuştur.

Aynı süre içindeki ithalat değişimi de izlenmiştir. Buna göre, 2010 yllında 118 milyon Dolar olan Türkiye'nin toplam ithalatı, 2017 yılında yaklaşık 627 milyon Dolar olmuştur. Sektörün ithalat ortalaması ise 330 milyon Dolar iken, bu veriler Türkiye'nin tohum dış ticaretinde net ithalatçı olduğunu ortaya koymaktadır.

Çizelge 1'de temel ticaret ortağ ülkelerle gerçekleştirilen ihracat ve ithalatın 2000 ve 2017 yılları arasındaki değişimi gösterilmiştir. Bu verilere göre, İspanya haricinde tüm ülkelerle ihracatımız önemli oranda artarken, en belirgin artış Ukrayna, Romanya ve Macaristan ile olan ihracatımizda gözlenmiştir. Tohum ithalatında ise Hollanda hariç tüm ülkelerden ithalat artmıştır.

Çizelge 1. Türkiye'nin 2000 ve 2017 yılları arasında Ülkelere Göre Tohumluk İhracat ve İthalat Değiş̧imi (\%)

\begin{tabular}{lrr}
\hline & $\mathbf{2 0 1 7 - 2 0 0 0}$ & \multicolumn{1}{c}{$\mathbf{2 0 1 7 - 2 0 0 0}$} \\
İhracat Değişimi & İthalat Değişimi \\
\hline Fransa & 85,52 & 260,71 \\
Hollanda & 253,61 & $-33,95$ \\
Almanya & 376,13 & 17,27 \\
İtalya & 219,65 & 756,00 \\
İspanya & $-50,08$ & $3.091,63$ \\
Macaristan & $1.698,88$ & $3.082,46$ \\
Romanya & 3516,32 & 339,37 \\
Ukrayna & $21.476,79$ & $2.273,08$ \\
Rusya & 551,08 & 210,92 \\
Irak* & 729,57 & $1.017,82$ \\
\hline
\end{tabular}

*Değişim Irak için İhracatta (2017-2003); İthalatta (2017-2004) yıllarını kapsamaktadır.

Dış Ticaret Değişiminin Analizi

\section{Betimleyici İstatistikler ve İlişski Analizi}

Analiz aşamasına geçmeden önce, analize konu olan değişkenlerin uyumluluğunun değerlendirilmesi gerekmektedir. Bu noktada, temel değerlendirmeye dahil edilen Irak ile olan dış ticarete ilişkin verilerin kesikli ve yetersiz olması nedeniyle, Irak verilerinin istatistiksel analizden çıkarıldığının bir kez daha not edilmesi gerekmektedir. Zaman ve yatay kesitten bağımsız yapılan veri uygunluğu değerlendirmesine göre 15 yılda 9 ülkeye yapılan toplam tohumluk ihracatı ortalaması yaklaşık olarak 7.4 milyon Dolar, ithalat ortalaması ise 33 milyon Dolar'dır. Türkiye'nin ilgili yıllar için ortalama tohumluk üretimi ise yaklaşık 427 bin tondur.

Çizelge 2'de verilerin zaman ve yatay kesit kısıtlarından bağımsız olarak doğrusal dağılıp dağılmadıklarını anlamak için hesaplanan JarqueBera istatistiğine yer verilmiştir. Jarque-Bera istatistiği serilerin 0 çarpıklık ve 3 basıklık değeri ile normal dağıldığını varsaymaktadır (Jarque ve Bera, 1980; 1981). Verilen olasılık (p) değerlerine göre, yer verilen tüm seriler \%99 önem düzeyinde normal dağılmamaktadır. Ancak panel veri özelliklerinin yansıtılmadığı bu testten çıkan sonuçla doğrudan bir normalleştirme değerlendirilmesi uygun görülmemiş̧tir.

Öncelikle Türkiye'nin tohum ihracat geliri ve ilgili bağımsız değişkenler arasındaki ilişkilerin yönü ve anlamlılığı panel veri analizinin doğası gereği zamana ve yatay kesite bağlı olarak ayrı ayrı değerlendirilmiş ve bulgular Çizelge 3 ve Çizelge 4'te sunulmuştur.

$\mathrm{Bu}$ verilere göre, bağımlı değişken ile bağımsız değişkenler arasındaki yatay kesite bağlı korelasyon yönü beklentilere uygun ve istatistiksel olarak anlamlıdır. Zamana bağlı doğrusal ilişkide ise ithalatçı ülkenin yerel para birimi cinsinden döviz kuru, ülkelerin ekonomik başkentleri ile İstanbul arasındaki mesafe ve ülkelerin nüfusu arasında anlamlı bir ilişki bulunmaktadır.

Bağımsız değişkenler arasındaki ilişki düzeyi ise "ilişkinin yokluğu" yani korelasyon hipotezinin reddi esas alınarak değerlendirilmiştir. Bu verilere göre, ticaret ortağı ülke geliri ve döviz kuru ile Türkiye'nin geliri ve döviz kuru arasında doğrusal ilişki bulunmaması, ayrıca Türkiye'de gerçekleşen üretim miktarının da ilgili makro göstergelerle ilişkisizliği seçilen açıklayıcı değişkenlerin uygunluğu ile ilgili bilgi vermektedir.

Ayrıca, değişkenler arasındaki zamana bağlı korelasyon da incelenmiş ve bulgular Çizelge 5'te sunulmuştur.

Çizelge 5'te gösterilen bağımsız hareket seyri, ülkelere göre ilişkiyle benzer özellik göstermektedir. Burada ek olarak, Türkiye tohum üretim miktarının Türk Lirası'nın Dolar değeri haricindeki tüm serilerle doğrusal ilişkisinin olmadığı görülmüştür. Buna göre, ihracat denkleminde seçilmesi gereken değişkenler için özellikle milli gelir ve döviz kuru arasında çapraz tercih yapmanın daha doğru olacağı anlaşılmaktadır.

Doğrusal ilişki analizinin ardından, değişkenlerin birlikte hareket edip etmediğini anlamak üzere kovaryans analizi yapılmıştır. Kovaryans analizinin boş hipotezi araştırmamız kapsamında Türkiye'nin tohum ihracat gelirinin bağımsız değişkenlerle birlikte hareket etmediği varsayımına dayalıdır. 
Çizelge 2. Analize konu olan değişkenlerin betimleyici istatistikleri

\begin{tabular}{|c|c|c|c|c|c|}
\hline & Ortalama & $\begin{array}{c}\text { En } \\
\text { Büyük }\end{array}$ & $\begin{array}{c}\text { En } \\
\text { Küçük }\end{array}$ & $\begin{array}{c}\text { Jarque- } \\
\text { Bera } \\
\end{array}$ & $\begin{array}{c}\mathrm{p}^{-} \\
\text {değeri }\end{array}$ \\
\hline İhracat Geliri (ABD Doları) & 7389974 & 43654338 & 42655.00 & 593.3264 & 0.00 \\
\hline İthalat Gideri (ABD Doları) & 32801177 & $3.93 \mathrm{E}+08$ & 34993.00 & 1055.023 & 0.00 \\
\hline Diğer ülke KBMG (ABD Doları) & 25592.77 & 52121.20 & 1817.997 & 15.13186 & 0.00 \\
\hline Türkiye'nin KBMG (ABD Doları) & 9610.352 & 11580.76 & 7347.997 & 10.06841 & 0.006 \\
\hline Diğer ülke Döviz kuru (ABD Doları/Yerel Para Birimi) & 30.32583 & 286.4900 & 0.900000 & 289.1208 & 0.00 \\
\hline Türkiye'nin Döviz kuru (ABD Doları/TL) & 1.562314 & 2.720009 & 0.625219 & 24.25858 & 0.00 \\
\hline Nüfus & 54105952 & $1.47 \mathrm{E}+08$ & 9843028. & 29.80574 & 0.00 \\
\hline Türkiye Üretim Miktarı (Ton) & 426744.8 & 896298.0 & 117643.0 & 10.87499 & 0.004 \\
\hline
\end{tabular}

Çizelge 3. Türkiye tohum ihracat geliri ile bağımsız değişkenler arasında ülkeler ve zamana bağlı korelasyon

\begin{tabular}{lcccc}
\hline & \multicolumn{2}{c}{ Ülkelere Bağlı Korelasyon } & Zamana Bağl Korelasyon \\
\hline İhracat Geliri & $\begin{array}{c}\text { Pearson Kor. } \\
\text { Katsayısı - ülke }\end{array}$ & $\begin{array}{c}\text { p- değeri } \\
\text { Diğer ülke KBMG }\end{array}$ & $\begin{array}{c}\text { Pearson Kor. Katsayısı - } \\
\text { zaman }\end{array}$ & 0.41 \\
Türkiye'nin KBMG & 0.576 & $0.00^{* * *}$ & 0.07 & 0.02 \\
Diğer ülke Döviz kuru & 0.48 & $0.00^{* * *}$ & -0.17 & $0.04^{* *}$ \\
Türkiye'nin Döviz kuru & -0.19 & $0.02^{* *}$ & -0.063 & 0.46 \\
Nüfus & 0.37 & $0.00^{* * *}$ & 0.58 & $0.00^{* * *}$ \\
Türkiye Üretim Miktarı & 0.49 & $0.00^{* * *}$ & 0.04 & 0.67 \\
Mesafe (Km) & 0.48 & $0.00^{* * *}$ & 0.29 & $0.00^{*}$ \\
\hline
\end{tabular}

$* * * \% 99 ; * * \% 95$

Çizelge 4. Bağımsız Değişkenler arasında ticarete konu olan ülkelere bağlı korelasyon

\begin{tabular}{|c|c|c|c|c|c|}
\hline & $\begin{array}{c}\text { Pearson Kor. } \\
\text { Katsayısı }\end{array}$ & $\begin{array}{c}\mathrm{p}^{-} \\
\text {değeri }\end{array}$ & & $\begin{array}{c}\text { Pearson Kor. } \\
\text { Katsayısı }\end{array}$ & $\begin{array}{c}p^{-} \\
\text {değeri }\end{array}$ \\
\hline $\begin{array}{l}\text { Türkiye'nin KBMG \& Diğer } \\
\text { ülke KBMG }\end{array}$ & 0.156264 & $0.0624^{*}$ & $\begin{array}{l}\text { Diğer ülke KBMG \& } \\
\text { Türkiye'nin Döviz kuru }\end{array}$ & 0.099046 & 0.2392 \\
\hline $\begin{array}{l}\text { Türkiye'nin KBMG \& Döviz } \\
\text { kuru - Diğer ülke }\end{array}$ & -0.005450 & 0.9485 & $\begin{array}{l}\text { Diğer ülke KBMG \& } \\
\text { Üretim Miktarı }\end{array}$ & 0.124905 & 0.1372 \\
\hline Türkiye'nin KBMG \& Nüfus & 0.005497 & 0.9480 & $\begin{array}{l}\text { Üretim Miktarı \& } \\
\text { Nüfus }\end{array}$ & 0.005584 & 0.9472 \\
\hline $\begin{array}{l}\text { Türkiye'nin Döviz kuru \& } \\
\text { Diğer ülke Döviz kuru }\end{array}$ & 0.023142 & 0.7838 & & & \\
\hline
\end{tabular}

$* \% 90$

Çizelge 5. Bağımsız değişkenler arasında zamana bağlı korelasyon

Türkiye'nin KBMG \& Diğer ülke KBMG

Türkiye'nin KBMG \& Diğer ülke Döviz kuru

Türkiye'nin Döviz kuru \& Nüfus

Türkiye'nin Döviz kuru \& Diğer ülke Döviz kuru

Diğer ülke KBMG \& Türkiye'nin Döviz kuru

Diğer ülke KBMG \& Üretim Miktarı

Diğer ülke KBMG \& Nüfus
Pearson Kor. Katsayısı

0,022198

$-0,023132$

0,000270

0,038778

$-0,014754$

$-0,019999$

$-0,070839$ p- değeri

0,7924

0,7839

0,9974

0,6456

0,8612

0,8126

0,4005 
Çizelge 6. Türkiye tohum ihracat geliri ile bağımsız değişkenler arasında ülkeler ve zamana bağlı kovaryans

\begin{tabular}{|c|c|c|c|c|}
\hline \multirow[b]{2}{*}{ İhracat Geliri (ABD Doları) } & \multicolumn{2}{|c|}{ Ülkelere Bağlı Kovaryans } & \multicolumn{2}{|c|}{ Zamana Bağlı Kovaryans } \\
\hline & Kovaryans Değeri & $p^{-}$değeri & $\begin{array}{l}\text { Kovaryans } \\
\text { Değeri }\end{array}$ & $p^{-}$-değeri \\
\hline Diğer ülke KBMG & $2.55 \mathrm{E}+10$ & $0,00 * * *$ & & \\
\hline Türkiye'nin KBMG & $4.46 \mathrm{E}+09$ & $0,00 * * *$ & & \\
\hline Diğer ülkenim Döviz kuru & -90465331 & $0.02^{* *}$ & -74719746 & $0,04^{* *}$ \\
\hline Türkiye'nin Döviz kuru & 1152859. & $0,00 * * *$ & & \\
\hline Nüfus & $1.28 \mathrm{E}+14$ & $0,00 * * *$ & $1,38 \mathrm{E}+14$ & $0,00^{*}$ \\
\hline Üretim Miktarı & $7.97 \mathrm{E}+11$ & $0,00 * * *$ & $1,17 \mathrm{E}+09$ & $0,00^{*}$ \\
\hline Mesafe & $1.49 \mathrm{E}+09$ & $0,00 * * *$ & & \\
\hline
\end{tabular}

$* * * \% 99 ; * * \% 95$

Bu değerler ışığında ülkelere bağlı olarak kovaryansın büyük oranda anlamlı olduğu, zamana bağlı kovaryansın ise sadece ithalatçı ülkenin döviz kuru ile Türkiye'de tohum üretim miktarı ve nüfus ile birlikte hareket ettiği anlaşılmıştır. Son olarak, bağımsız değişkenler arasındaki birlikte hareket etme durumu yine ülkelere ve ilgili zaman dilimine bağlı olarak kovaryans analizi ile test edilmiştir. Açıklayıcı değişkenler arasındaki kovaryans değerlendirmesinde korelasyon katsayıları ile benzer bir sonuç elde edilmiştir. Buna göre, değişkenlerin analize dahil edilmesine nedensellik ilişkilerine göre karar verilmiştir.

\section{Veri Oluşum Süreci}

Araştırmanın analiz aşamasında önerilen ilk modelin düzeyde tahmini yapılmış ve değişkenler arasındaki ilişkilerin istatistiksel yansıması değerlendirilmiştir. İlk denklemden elde edilen tahmin sonuçları Çizelge 7'de sunulmuştur.

Çizelge 7. Türkiye'nin ihracat gelirine etki eden faktörlerin Panel En Küçük Kareler Tahmini (9 ülke*16 yıl=144 veri)

\begin{tabular}{llll}
\hline Değişken & Katsayı Tahmini & t-istatistiği & p-değeri \\
\hline $\mathbf{C}$ & -8992985 & -1.12 & 0.27 \\
$\mathbf{Y}_{\mathbf{i}}$ & 232.4082 & 4.11 & $0.00^{* * *}$ \\
$\mathbf{Y}_{\mathbf{j}}$ & 1329.277 & 1.44 & 0.15 \\
$\mathbf{E X C}_{\mathbf{i}}$ & -1942247 & -0.96 & 0.34 \\
$\mathbf{E X C}_{\mathbf{j}}$ & 1337.044 & 0.17 & 0.86 \\
$\mathbf{Q}_{\mathbf{i}}$ & 11.64917 & 1.64 & 0.10 \\
$\mathbf{N}_{\mathbf{j}}$ & 0.077557 & 6.31 & $0.00^{* * *}$ \\
$\mathbf{d}_{\mathrm{ij}}$ & -1690.227 & -1.54 & 0.13 \\
$\mathbf{A B}$ & -7591769 & -4.08 & $0.00^{* * *}$ \\
$\mathbf{R}^{2}$ & 0.56 & $\mathbf{F}(\mathrm{p})$ & $21.25(0.00)^{* * *}$ \\
$\mathbf{Y}^{-o r t}$ & 7389974 & $\mathrm{D}-\mathrm{W}$ istatistiği & 0.622 \\
\hline$* * * \% 99$ & & &
\end{tabular}

$\mathrm{Bu}$ birleştirilmiş tahmin sonuçlarına göre, tahmin denkleminin Türkiye'nin ihracat gelirini açıklama düzeyi \% 56’nın üzerindeki uyum iyiliği ve değişkenlerin bir arada anlamlılı̆̆ını gösteren $\mathrm{F}$ istatistiğinin değeri ile görülmektedir. Ancak, bu tahminin açıklayıcılığı hususunda karar vermek gerekmektedir. Birleştirilmiş panelde bağımlı değişken ortalaması 7.4 milyon Dolar iken, tahmin denkleminin sabit terim katsayıs - 8.9 milyondur. $\mathrm{Bu}$ tahminde böyle bir negatif ortalama, teorik beklentilere uygun değildir. Ayrıca, verilerin niteliği incelenirken görülen korelasyon ilişkileri sonuçlarına göre, Türkiye ve ticaret ortağı ülkelerin milli gelir ve döviz kuru değerlerinin bir arada değerlendirilmesinin tahminin açıklayıcılığını yükseltecek olsa da otokorelasyona yol açacağı öngörülmüştür. $\mathrm{Bu}$ nedenle, birleştirilmiş tahminden aralarında korelasyon ilişkisi bulunan bu değişkenlerden, ihracat odaklı tahmin yapılması nedeniyle ticaret ortağı ülkenin kişi başı milli geliri ile Türk Lirası'nın Dolar karşılığındaki değerini gösteren döviz kurunun kullanılması daha uygun bulunmuştur. $\mathrm{Bu}$ değişkenlerin eksiltilmesi sonucunda birleştirilmiş panel tahmin tekrar edilmiştir. 
Çizelge 8. Türkiye'nin ihracat gelirine etki eden faktörlerin azaltılmış değişkenlerle Panel En Küçük Kareler Tahmini (9 ülke*16 yll=144 veri)

\begin{tabular}{|c|c|c|c|}
\hline Değişken & Katsayı Tahmini & t-istatistiği & p-değeri \\
\hline $\mathrm{C}$ & 2013530 & 0.83 & 0.4080 \\
\hline$Y_{j}$ & 228.6657 & 4.08 & $0.0001^{* * *}$ \\
\hline $\mathbf{E X C}_{i}$ & -3202451 & -1.76 & $0.0812^{*}$ \\
\hline$Q_{i}$ & 20.55068 & 5.98 & $0.0000 * * *$ \\
\hline $\mathrm{N}_{\mathrm{j}}$ & 0.078051 & 6.42 & $0.0000 * * *$ \\
\hline$d_{i j}$ & -1748.054 & -1.86 & $0.0644^{*}$ \\
\hline $\mathrm{AB}_{\mathrm{j}}$ & -7367690 & -4.05 & $0.0001^{* * *}$ \\
\hline $\mathbf{R}^{2}$ & 0.55 & $F(p)$ & $27.97(0.00)^{* * *}$ \\
\hline Y-ort & 7389974 & $\mathrm{D}-\mathrm{W}$ istatistiği & 0.634018 \\
\hline
\end{tabular}

Bu denklemde açıklayıcılık gücünde önemli bir değişme görülmemiş ancak tahmincilerin istatistiksel anlamlılıkları bireysel olarak yükselmiştir. Buna karşın, zaman boyutunu da içeren tahmin sonuçları 2'den küçük Durbin-Watson istatistiğine göre pozitif korelasyona işaret etmektedir. Ayrica, tahmin denkleminin Jarque-Bera testine göre normal dağılım özellikleri incelenmiştir. 157.74 Jarque-Bera değeri ve bunun 0.00 olasılığına bağlı olarak hata terimlerinin normalliği hipotezi reddedilmiştir. Bunun ardından tespit edilen değişkenlerin logaritma alınarak doğrusallaştırılma durumları değerlendirilmiştir.

Çizelge 9'a göre, verilerin logaritma ile doğrusallaştırılmış formunda da normal dağglım özelliği gözlenmemiştir. Bu nedenle, tahmine devam etmeden önce, değişkenlerin zamana ve yatay kesit unsurlarına göre birim köklerinin incelenmesi gerekmektedir.

Çizelge 9. Doğrusallaştırılmış bağımlı ve bağımsız değişkenlerin normallik testi sonuçları

\begin{tabular}{lll}
\hline Değişken & Jarque-Bera & p-değeri \\
\hline $\operatorname{LnX}_{\mathrm{ij}}$ & 71.49 & $0.00^{* * *}$ \\
$\operatorname{LnY}_{\mathrm{j}}$ & 16.21 & $0.00^{* * *}$ \\
$\operatorname{LnEXC}_{i}$ & 56.54 & $0.00^{* * *}$ \\
$\operatorname{LnQ}_{\mathrm{i}}$ & 8.68 & $0.01^{* * *}$ \\
$\operatorname{LnN}_{\mathrm{j}}$ & 6.85 & $0.03^{* *}$ \\
$\operatorname{Lnd}_{\mathrm{ij}}$ & 29.00 & $0.00^{* *}$ \\
\hline$* * * \% 99 ; * * \% 95 ; * \% 90$ &
\end{tabular}

Tercih edilen değişkenlerin korelasyon ilişkileri, tercih denkleminin düzeyde mi yoksa farkta $\mathrm{ml}$ tahmin edileceğine dair bilgi edinmemizi sağlar. Bu nedenle, tüm değişkenlerin düzeyde birim köklerinin analiz edilmesi gerekmektedir. Eğer zamana bağlı korelasyon ilişkisi tespit edilirse, bu ilişkinin dönemler arası fark alınarak giderilip giderilmeyeceği eşbütünleşme testi sonuçlarına göre değerlendirilecek olmakla birlikte, değişkenlerin farkları alındığında durağanlaşıp durağanlaşmadığı yine birim kök testi uygulaması ile tespit edilmiştir.

Uygulanan Levin-Li-Chu (LLC) panel birim kök testinin boş hipotezi ortak birim kök olmadığına işaret etmektedir. Bu hipotez reddedilemezse, değişkenlerin yatay kesit unsurlarına bağlı olarak korelasyon özelliği gösterdiği anlaşılmaktadır. Seçilen tüm değişkenlerin birim kök testi sonuçları Çizelge 10'da gösterilmiştir.

Burada not edilmesi gereken bir husus bulunmaktadır. Türkiye'nin döviz kuru ve toplam tohumluk miktarı yatay kesitte tekrar eden veriler durumundadır. $\mathrm{Bu}$ nedenle, diğer değişkenler için istatistik değerleri sadece sabit katsayı ile hesaplanırken, bu iki değişken için istatistik hesabına yatay kesite göre dağılan doğrusal trend de eklenmiştir.

Çizelge 10'daki sonuçlara göre, analize konu olan tüm değişkenler düzeyde durağan değilken, birinci farkta bu hipotez \% 99 istatistiksel anlamlılık düzeyinde reddedilmiştir. Ancak, Türkiye'nin yatay kesitte tekrarlı tohumluk üretim miktarının birinci fark veri seti için LLC istatistiği ortak birim kökün ortadan kalktığını göstermemiştir. Buna karşın, trendin yatay kesit yani ülkelere göre dağılımını esas alan bir diğer ortak birim kök testi olan Breitung-t (Breitung, 2000) istatistiğine göre birim kök birinci farkta kalkmaktadır. Ayrıca, kukla değişken olarak ticaret birliklerinin etkisini ölçen $\mathrm{AB}$ üyeliği değişkeni ve yatay kesitte tam tekrarlı değişken olan mesafe değişkeni için birim kök analizi yapılmamıştır.

Değişkenlerin zamana bağlı otokorelasyon değerlendirmesi veri setinin zaman ilişkisi içerdiğini göstermiştir. $\mathrm{Bu}$ ispatın ardından verilerin eşbütünleşme ile tahmin edilip edilemeyeceğini anlamak için Pedroni eş-bütünleşme testi uygulanmıştır. Teste düzeyde değişkenlik gösteren ihracat geliri, ülkelerin kişi başı milli geliri, Türkiye'nin tohum ihracat miktarı ve TL-Dolar kuru değişkenleri dahil edilmiş ve bulgular Çizelge 11'de sunulmuştur. 
Çizelge 10. Bağımlı ve bağımsız değişkenler için birim kök test sonuçları

\begin{tabular}{lcccc}
\hline Değişken & \multicolumn{2}{c}{ Düzey } & \multicolumn{2}{c}{ Birinci Farkı } \\
\cline { 2 - 5 } & LLC & p-değeri & LLC & p-değeri \\
\hline $\mathbf{X}_{\mathrm{ij}}$ & 0.02221 & 0.51 & -3.84694 & $0.0001^{* * *}$ \\
$\mathbf{Y}_{\mathrm{j}}$ & -1.68073 & $0.05^{* *}$ & -3.79215 & $0.0001^{* * *}$ \\
$\mathbf{E X C}_{\mathrm{i}} \mathrm{a}$ & 7.44569 & 1.0 & -4.16695 & $0.0000^{* * *}$ \\
$\mathbf{Q}_{\mathrm{i}}-\mathbf{L L C}^{\mathrm{a}}$ & 2.76924 & 0.99 & 5.71910 & 1.0000 \\
$\mathbf{Q}_{\mathrm{i}}-$ Breitung-ta & 0.68697 & 0.75 & -3.16320 & $0.0008^{* * *}$ \\
$\mathbf{N}_{\mathrm{j}}$ & -1.27251 & 0.10 & -3.58403 & $0.0002^{* * *}$ \\
\hline$* * * 0$
\end{tabular}

Çizelge 11. Değiş̧enler arası Eş-bütünleşme testi sonuçları

$\mathrm{H}_{\mathrm{o}}$ : Değişkenler eş-bütünleşme ile tahminine gerek yoktur.

\begin{tabular}{lrl} 
Panel-v & 1.693499 & $0.0452^{* *}$ \\
Panel-rho & -0.311145 & 0.3778 \\
Panel - PP & -1.867389 & $0.0309^{* *}$ \\
Panel - ADF & -1.388850 & $0.0824^{* * *}$ \\
Grup-rho & 0.713536 & 0.7622 \\
Grup-PP & -8.176102 & $0.0000^{* * *}$ \\
Grup-ADF & -2.174176 & $0.0148^{* *}$ \\
\hline \multicolumn{1}{c}{$* * * \% 99 ; * * \% 95 ; * \% 90$} &
\end{tabular}

Test sonuçlarına göre, modelin tahmininde zamana bağlı otokorelasyonun eşbütünleşme tahmini aracılığıyla giderilebileceği sonucuna ulaşılmıştır. Bu aşamadan sonra panel tahminin yöntemine karar vermek gerekmektedir. Bu amaçla, veri setindeki yatay kesit etkisinin yani ülkelere göre değişimin varlığı incelenmiştir. Yatay kesit bağımlılığı, bağımlı değişkendeki varyasyonun yatay kesit veri noktalarına göre değişip değişmediğinin tespitine dayalıdır. Bu tespit bizim çalışmamız için Türkiye'nin yıllar içinde elde ettiği ihracat gelirinin ülkelere göre değişip değişmediğinin ölçülmesine odaklanmıştır. Bu inceleme Hausman Yatay Kesit Bağımlılık Testi ile yapılmıştır.

Metodolojinin açıklandığı bölümde testin hipotezi model tahmininin Tesadüfi Etkiler yöntemine göre yapılması gerektiğine atıfta bulunulmaktadır. Modelde zamana bağll varyasyon tespit edildiği ve değişimin eş-bütünleşme yöntemine göre analiz edilmesi gerektiği sonucuna ulaşıldığı için, bu testin gerçekleştirilmesi amacıyla öncelikle yatay kesite bağlı tesadüfi etkiler tahmini yapılması ve bu tek yönlü tahmin sonuçlarına göre yatay kesit bağımlılığının test edilmesi gerekmektedir. Tekrarlı değişkenlerle yapılacak testin sonuçları, $\mathrm{X}^{2}$ değerinin hesaplanamaması nedeniyle geçerli olmayacaktır. Dolayısıyla, düzeyde yatay kesit bağımlılığının daha açıklayıcı şekilde değerlendirilmesi için bu tekrarlı ve kukla değişkenlerin çıkarılması ile test yinelenmiş ve sonuçlar Çizelge 12'de sunulmuştur.
Çizelge 12. Nicel değişkenlerle Hausman yatay kesit belirleme testi sonuçları

$\mathrm{H}_{0}$ : İhracat gelirinin belirleyicilere göre tesadüfi etkilere göre tahmin edilmesi uygundur.

Belirleyiciler: $\mathbf{E X C}_{\mathrm{i}} ; \mathrm{Y}_{\mathrm{j}} ; \mathrm{N}_{\mathrm{j}}$

\begin{tabular}{|l|c|c|c|}
\hline Hausman - X & S.D. & p-değeri \\
\hline Yatay Kesit Tesadüfi & 49.22 & 3 & $0.00^{* * * *}$ \\
\hline Hata terimi bileşenleri \\
\hline Tesadüfi yatay kesit & 2732305 & 0.28 \\
\hline Rastlantısal hata & 4324569 & 0.72 \\
\hline
\end{tabular}

$* * * \% 99 ; * * \% 95 ; * \% 90$

$\mathrm{Bu}$ analiz sonuçlarına göre, hipotez reddedilmektedir. Bu düzey tahmininin tesadüfi etkilere göre değil, sabit etkiler yaklaşımına göre gerçekleştirilmesi gerekliliğini göstermektedir. $\mathrm{Bu}$ durum, panel tahmininden elde edilen yatay kesit hata bileşenleri ortalamasının \% 90'da dahi istatistiksel anlamsızlığını gösteren $\mathrm{p}$ değerinden de anlaşılmaktadır.

Buna ek olarak, bu değişkenler arasında sabit etkiler tahmininin mümkün olup olmadığına Olabilirlik Oranı ile de bakılmıştır. Çizelge 13'te gösterilen sonuçlar sabit etkiler tahminin yani, kukla değişkenler aracılığı ile farklı yatay kesitler için farklı sabit terim elde edilmesi sürecinin veri niteliğine daha uygun olduğu sonucuna ulaşılmıştır.

Çizelge 13. Nicel değişkenlerle Olabilirlik Oranı Testi sonuçları

\begin{tabular}{|c|c|c|c|}
\hline \multicolumn{4}{|c|}{$\begin{array}{l}\mathrm{H}_{0}: \quad \text { İhracat gelirinin } \\
\text { birleştirilmiş yöntemle tahmin }\end{array}$} \\
\hline \multicolumn{4}{|c|}{ Belirleyiciler: $\mathrm{EXC}_{\mathrm{i}} ; \mathrm{Y}_{\mathrm{j}} ; \mathrm{Q}_{\mathrm{i}} ; \mathrm{N}_{\mathrm{j}}$} \\
\hline \multicolumn{2}{|c|}{ Yatay Kesit - F } & S.D. & p-değeri \\
\hline Yatay Kesit Sabit & 12.34 & 8 & $0.00^{* * *}$ \\
\hline \multicolumn{2}{|l|}{ Yatay Kesit $-\mathrm{X}^{2}$} & S.D. & p-değeri \\
\hline Yatay Kesit Sabit & 80.88 & 8 & $0.00 * * *$ \\
\hline
\end{tabular}

Ancak, değişkenler arası bağımlılı̆̆ın eş-bütünleşme yaklaşımına göre de test edilmesi gerekmektedir. Buna göre, fark denkleminin tesadüfi etkiler tahmininin uygunluğuna bakılmıştır. Bu aşamada nicel değişkenlerle analiz tekrar edilmiş ve test bulguları Çizelge 14 ve 15 'te sunulmuştur. 
Çizelge 14. Birinci farkta nicel değişkenlerle Hausman Yatay Kesit Belirleme Testi sonuçları

\begin{tabular}{|c|c|c|c|}
\hline \multicolumn{4}{|c|}{$\begin{array}{l}\mathrm{H}_{0} \text { : İhracat gelirinin belirley } \\
\text { etkilere göre tahmin edilmesi }\end{array}$} \\
\hline \multicolumn{4}{|c|}{ Belirleyiciler: $\Delta \mathrm{EXC}_{\mathrm{i}} ; \Delta \mathrm{Y}_{\mathrm{j}} ; \Delta \mathrm{N}_{\mathrm{j}}$} \\
\hline \multicolumn{2}{|c|}{ Hausman $-\mathrm{X}^{2}$} & S.D. & p-değeri \\
\hline Yatay Kesit Tesadüfi & 0.96 & 3 & 0.81 \\
\hline \multicolumn{4}{|l|}{ Hata terimi bileşenleri } \\
\hline Tesadüfi yatay kesit & \multicolumn{2}{|l|}{0.00} & 0.00 \\
\hline Rastlantısal hata & \multicolumn{2}{|c|}{3581394} & 1.00 \\
\hline
\end{tabular}

$\mathrm{Bu}$ analiz sonucu, test istatistiğinin olasılık değeri nedeniyle sifir hipotezinin reddedilemeyeceğini göstermiştir. Buna göre, tahmin tesadüfi etkiler yaklaşımına göre yapılabilir sonucuna ulaşılabilir. Ancak, hata bileşenleri içerisinde yer alan tesadüfi yatay kesit unsurlarının varyansının sıfır olması tesadüfi etkiler tahmini gerekliliğini ortadan kaldırmaktadır. Buna göre; modelimizin birleştirilmiş panel yaklaşımina göre tahmin edilmesi gerektiği sonucuna ulaşılmıştır. Çizelge 15 'te gösterilen Olabilirlik Oranı test sonuçları bu yaklaşımı doğrulamıştır.
Çizelge 15. Birinci farkta nicel değişkenlerle Olabilirlik Oranı Testi sonuçları

$\mathrm{H}_{0}$ : İhracat gelirinin belirleyicilere göre birleştirilmiş yöntemle tahmin edilmesi uygundur.

\begin{tabular}{|l|l|l|l|}
\hline \multicolumn{3}{|l|}{ Belirleyiciler: $\Delta \mathbf{E X C}_{\mathrm{i}} ; \Delta \mathrm{Y}_{\mathrm{j}} ; \Delta \mathrm{N}_{\mathrm{j}} ; \Delta \mathbf{Q}_{\mathrm{i}}$} \\
\hline Yatay Kesit - F & S.D. & p-değeri \\
\hline Yatay Kesit Sabit & 0.17 & 8 & 0.99 \\
\hline Yatay Kesit - X & & S.D. & p-değeri \\
\hline Yatay Kesit Sabit & 1.51 & 8 & 0.99 \\
\hline
\end{tabular}

$\mathrm{Bu}$ değerlendirmelerden yola çıkarak, tohumluk ihracat gelirinin tespit edilen açıklayıcı değişkenlerle olan ilişkisi takip eden bölümde tahmin edilmiştir.

\section{Model Tahmin Sonuçları}

Gerçekleştirilen analiz ve test süreçleri sonucunda, Türkiye'nin dokuz ticaret ortağı ülkeye 2000-2015 yılları arasında gerçekleştirdiği ihracattan elde ettiği gelirin yıllar içerisindeki farkına tespit edilmiş değişkenlerin etkisinin birleştirilmiş panel yöntemi ile tahmin sonuçları Çizelge 16'da gösterilmiştir.

Çizelge 16. Türkiye'nin ihracat gelirinin yıllar arası farkına etki eden faktörlerin Panel En Küçük Kareler Yöntemiyle Tahmin Sonuçları (9 ülke*15 yıl=135 veri)

\begin{tabular}{lccc}
\hline Değişken & Katsayı Tahmini & t-istatistiği & p-değeri \\
\hline $\mathbf{C}$ & 139192.7 & 0.125 & 0.9 \\
$\Delta \mathrm{Y}_{\mathrm{j}}$ & 868.3983 & 1.823 & $0.07^{*}$ \\
$\Delta \mathrm{EXC}_{\mathrm{i}}$ & -2807339 & -1.912 & $0.06^{*}$ \\
$\Delta \mathbf{Q}_{\mathrm{i}}$ & 2.139428 & 0.438 & 0.7 \\
$\Delta \mathrm{N}_{\mathrm{j}}$ & -1.747454 & -1.648 & $0.10^{*}$ \\
$\mathrm{~d}_{\mathrm{ij}}$ & 212.5923 & 0.463 & 0.64 \\
$\mathrm{AB}_{\mathrm{j}}$ & 203683.4 & 0.266 & 0.8 \\
$\mathrm{R}^{2}$ & 0.09 & $\mathbf{F}(\mathbf{p})$ & $2.16(0.05)^{* *}$ \\
$\mathrm{Y}$-ort & 513219.6 & D-W istatistiği & 1.87 \\
\hline
\end{tabular}

$* * * \% 99 ; * * \% 95 ; * \% 90$

Bulgulara göre, özellikle kategorik değişkenlerin bireysel parametre tahminlerinin açıklayıcılık oranı düşüktür. Bununla, birlikte uyum iyiliği de değişkenlerin bağımlı değişkendeki varyasyonu \%9 oranında açıkladığını göstermiştir. Düzeyde gerçekleştirilecek En Küçük Kareler tahmininde bu düşük açıklayıcılı oranı tahminin değerlendirilmesinin gerekliliğini ortadan kaldırırken, panel araştırmalarda buna rağmen sonuç değerlendirmesi yapıldığı görülmüştür (Jansen og ve Schulz, 2006; Giulietti ve ark., 2004). Ayrica, 1.87 değerindeki Durbin-Watson istatistiği, serilerdeki otokorelasyonun fark tahmini ile giderildiğini göstermektedir.

Sonuçlara göre, hiçbir ekonomik etkinin bulunmadığ ortamda, Türkiye'nin ihracat gelir ortalaması
139192.7 Dolar olarak bulunmuştur. Gelirin \% 27'si hiçbir etkene bağlı olmadan oluşmaktadır. Ticaret ortağı ülkelerin dönemler arası kişi başı milli gelirindeki bir birimlik (bir Dolar) artışın Türkiye'nin ihracat gelirini toplam olarak 868 Dolar artırdığ görülmektedir. Ülkelerin nüfusundaki artış, ihracat gelirini negatif yönde etkilemektedir. Üretim miktarı artışı ise, ihracat gelirini iki kattan fazla artırmaktadır. Ticaret ortağı ülkenin AB üyesi olması durumunda, ihracat gelirinin 203683 Dolar arttığ anlaşlmıştır. $\mathrm{Bu}$ durum, henüz ortak piyasa düzenlerine uyumu sağlanmamış sektör için, gelecekte daha pozitif beklentilere sahip olunması ve geleneksel ticaret ilişkilerinin sürdürülmesi ile ilişkilendirilebilir.

$\mathrm{Bu}$ pozitif etkilere karşı, beklentilerin tersine Türk Lirası'nın değer kaybının ihracat gelirinin dönemler 
arası farkını olumsuz etkilediği görülmüştür. Türk Lirası'nın dönemler arasında Dolar'a karşı 0.01'lik değer kaybının, tohumluk ihracat gelirini yaklaşık 28 bin Dolar azalttığı anlaşılmaktadır. Ayrıca, nakliye masraflarını değerlendirmek üzere kullanılan ticari merkezler arasındaki uzaklığın pozitif etkisi, nakliye masraflarmn ihracat gelirini olumsuz yönde etkilemediğinin bir göstergesi olarak belirmektedir. Burada göz önünde bulundurulması gereken özel bir husus mesafe değişkeninin İstanbul merkeziyle alınmış olmasıdır. Ana ticaret ortakları ile gerçekleştirilen kara ve deniz ticareti merkezinin İstanbul olduğu öngörüsüyle kurgulanan bu mesafe değişkeni, ürünün nihai teslim noktası ile doğrudan ilişkilendirilmemiştir. Bu nedenle, tohumluk tür ve çeşidine bağlı olarak yapılacak bir kurgu da mesafe değişkeninin etkisinin farklı olabileceği düşünülebilir.

\section{SONUC}

Farklı iklim kuşaklarına bir arada ev sahipliği yapan Türkiye, tohumluk yetiştiriciliğinde de artan büyük ölçekli yatırımlar ve örgüt yapısı ile bilinçlenmenin ön plana çıkması sonucunda önemli bir tohum üretici ve ihracatçısı ülke konumuna gelmiştir. Ancak, üretim ve ihracat miktarında, başta yağlı tohumlar ve hububat tohumları olmak üzere, önemli sıçramalar meydana gelirken, dünyadaki gelişmelere bağlı olarak ihracat gelirinin beklentilerin altında kaldığı anlaşılmaktadır.

Her ne kadar Türkiye tohumluk dış ticaretinde net ithalatçı konumunda da olsa, artan yatırımlar ve büyüyen sektör sayesinde ihracatın ithalatı karşılama oranını \% 20'nin üzerine çıkmıştır. Özellikle 2015 yılında Rusya'ya olan ihracatın düşmesinden kaynaklanan net ihracat geliri düşüklüğü göz önünde bulundurularak değerlendirildiğinde dahi, 2010 yılı itibariyle tohum ihracatındaki artış seyrinin süreklilik kazandiğı söylenebilir.

Çalışmamız önemi artan bir tarımsal çıktı olan tohum ihracatını etkileyen faktörlerin ticaret ortağı ülkeler esas alınarak incelenmesi amaciyla gerçekleştirilmiştir. Çalışma amacı doğrultusunda, Türkiye'nin temel ticaret ortağ gerçekleştirilen tohumluk dış ticareti 2000-2017 yılları arasında hacim itibariyle değerlendirilmiştir. Bu yıllar arasında Türkiye'nin ihracatının oransal olarak en fazla arttığı ülkeler Ukrayna, Romanya ve Macaristan iken, ithalatta İspanya, Macaristan ve Ukrayna ile olan ilişkilerde belirgin artış gözlenmiştir.

Üretim ve ticaret verilerinin genel değerlendirilmesinin ardından, çalışma kapsamında, veri yeterliliği göz önünde bulundurularak, Irak haricindeki 9 temel ticaret ortağına 2000-2015 yılları arasında gerçekleştirdiğimiz ihracattan elde edilen geliri etkileyen faktörler, nakliye masraflarmın ve ticaret birliklerinin etkisi de eklenmek suretiyle, panel veri analizi yaklaşımı çerçevesinde incelenmiştir.
Çalışmada, ticari merkezlerin yakınlığı ve dolayısıyla nakliye masraflarının göreceli olarak daha düşük olduğu öngörülen ülkeler arasındaki ticari ilişkilerin daha yoğun olması varsayımına dayanan yer çekimi modelini uygulamak hedeflenmiştir. Bu uygulamada sadece Türkiye'nin söz konusu dokuz ülkeye yapmakta olduğu ihracattan elde ettiği geliri etkileyen faktörler incelenmiştir. $\mathrm{Bu}$ nedenle, ticaret ortağ $\breve{g}_{1}$ ükenin kişi başı milli geliri, Türk Lirası'nın Dolar cinsinden değeri, Türkiye'de yetiştirilen tohumluk miktarı, nakliye masrafları göstergesi olarak İstanbul ve ticaret ortağ 1 ülkenin ekonomik başkenti ile ticaret ortağ̣ ülkenin Avrupa Birliği üyeliğini gösteren kukla değişken Türkiye'nin brüt tohumluk ihracat gelirinin belirleyicileri olarak analize konu edilmiştir.

Panel veri analizinin temel istatistiksel testleri, otokorelasyon ve yatay kesit bağımlılığını test etmek üzere uygulanmıştır. Bu değerlendirmeler sonrasında 9 ülke ile 16 yılllk ihracat ilişkisini yorumlamada en uygun modelin birleştirilmiş panel tahmini olduğu anlaşılmıştır. Birleştirilmiş panelde birinci farkta tahminin, yatay kesit ve zaman unsurundan bağımsız olarak ama yıllara bağlı değişim göz önünde bulundurularak yapılmasını esas almıştır.

$\mathrm{Bu}$ analitik değerlendirme sonucunda bir ylllık fark esas alınarak elde edilen parametre tahminleri kısaca şu şekilde değerlendirilebilir. Ticaret ortağ ülkenin kişi başı milli gelir artışı, Türkiye tohumluk üretim artışı ve ticaret ortağı ülkenin $\mathrm{AB}$ üyesi olma durumu Türkiye'nin dönemler arası ihracat geliri değişimini pozitif yönde etkilemektedir. Türkiye'nin tohumluk üretimi ve bu alanda yatırımı artırmasının ihracat potansiyelini artıracağ 1 görüşü sektörün güçlendirilmesine yönelik politika önerilerinin giderek daha fazla önem kazanacağına bir işaret olarak görülebilir. Ayrıca, AB üyesi ülkelerle olan ticari ilişkilerin pozitif etkisini, Gümrük Birliği'ne tarım ve gıda ürünlerinin henüz dahil edilmemesine referansla, sınır komşuluğu ve geleneksel ticaret ağları ile ilişkilendirilebilmektedir. Bununla birlikte, Akdeniz iklim kuşağındaki ülkelerle, tüm ürün gruplarında olduğu gibi, tohumluk ticaretinin de geçmişi gözden kaçırılmamalıdır. Ayrıca, 2010 yılı itibariyle üzerinde durulan Gümrük Birliği uygulamalarına üyelik sonrası tarım ticaretinin de dahil edilmesi ve ortak piyasa düzenlemelerinden istifade edilmesi durumunda bu üyelik etkisinin daha da yükselmesi beklentiler dahilindedir (Pekizoğlu, 2008).

Buna karşın, ticaret ortağı ülkede nüfus artışı ve Türk Lirası-Dolar döviz kuru değişiminin ihracat gelirini negatif yönde etkilediği görülmüştür. Bu etkilerden nüfus artışı, gelir dağılımı ve kişi başı milli gelir değişimine göre değerlendirildiğinde, beklentilere uygundur. Ancak, Türk Lirası'nın uluslararası ticaret değişim birimi Dolar karşısındaki değer kaybının ihracat gelirini olumlu etkilemesi ve fakat ülkenin net ithalatçı olması durumunda ticaret dengesini negatif 
yönde etkilemesi beklenir. $\mathrm{Bu}$ beklentilere karşın, negatif yönlü etki, ticaret ortağı ülkelerin döviz kuru değişimleri ile ilişkilidir. Çoklu doğrusal bağıntıdan kaçınmak üzere diğer ülke döviz kuru model tahmininde kullanılmamıştır.

Döviz kuru etkisinin değerlendirilmesinde temel etkenlerden birisinin ticaret ortağ $\breve{g}_{1}$ ülke para birimlerinin de Dolar karşısında değer kaybı olduğu göz önünde bulundurulmalıdır. Bu durum, özellikle Rusya Federasyonu Ruble devalüasyonunun 2015 yılında yol açtığı ihracat geliri düşüşünde kendini göstermektedir. 2000-2015 yılları arasında ana ticaret ortakları Rusya Federasyonu ve Ukrayna'da gözlenen devalüasyon dikkat çekicidir. Bir Dolar 2000 yılında 5.44 Grivna iken, 2015 yılında 21.85 Grivna olmuştur. $\mathrm{Bu}$ durum Ruble için de 28.13'ten 60.94'e bir değer kaybına işaret etmiştir. Türk Lirası'ndan daha fazla değer kaybeden bu para birimleri, Türkiye'nin bu ülkelerle olan tohum ihracatından daha fazla ithalatını olumlu yönde etkilemiştir.

$\mathrm{Bu}$ bulgulara göre, Türkiye'nin tohum ihracatını artırmada en önemli itkilerin başında tohumluk üretiminin artırılması gerekliliği göze çarpmaktadır. Her ne kadar açıklayıcılık oranı düşük bir tahmin denkleminden elde edilmiş olsa da, bu bulgular sektörün yatırımı artırmasının Türkiye'nin hem girdi bağımlılığını azaltacağı hem de nihai ürün olarak tohumluk ticaretinden elde edeceği gelirin artacağına işaret etmişstir.

\section{TEŞEKKÜR}

Bu araştırma, Akdeniz Üniversitesi Ziraat Fakültesi Tarım Ekonomisi Bölümü'nde 2018 yllında sunulan "Tohum Dış Ticaretine Döviz Kuru Dalgalanmalarının Etki Analizi” başlıklı Bitirme Çalışması bulgularından yararlanılarak hazırlanmıştır.

\section{KAYNAKÇA}

Anonim 2013. Production and Trade Statistics. http://www.fao.org/economic/ess/ess-trade/en/ (Erişim tarihi: 08.05.2018).

Anonim 2014. Seed Exports and Imports. http://www.worldseed.org/resources/seed-statistics/ (Erişim tarihi: 07.05.2018)

Anonim 2015a. 5553 Sayılı Tohumculuk Kanununun 10.Yll, Tohumculuk 2015, İstatistikler, Göstergeler, Çalıştaylar(1), web: (Erişim tarihi tarihi: 20.04.2018).

Anonim 2015b. TSÜAB, Tohumculuk Sektörünün Durumu ve Geleceği. Web: www.tsuab.org.tr (Erişim tarihi: 14.12.2017)

Anonim 2015c. TÜRKTOB, www.turktob.org.tr (Erişim tarihi: 18.03.2018).

Anonim 2015d. GTHB, www.tarim.gov,tr (Erişim tarihi: 24.02.2018).
Anonim 2015e.BÜGEM,https://www.tarim.gov.tr/sgb /Belgeler/SagMenuVeriler/BUGEM.pdf （Erişim tarihi: 24.02.2018)

Anonim 2016. https://mordorintelligence.com/indus try-reports. (Erişim tarihi: 18.04.2018)

Anonim 2017. TODAB, Tohumluk Dağıtım Sektörü Ulusal Strateji Raporu.

Arellano M 2003 Panel Data Econometrics. Oxford University Press, New York, 231 ss.

Anderson EJ, Wincoop Van E 2003. Gravity with Gravitas: A Solution to the Border Puzzle. The American Economic Review, 93(1):170-192.

Ahcar J, Siroën MJ 2017. Deep Integration: Considering the Heterogeneity of Free Trade Agreements Pontificia Universidad Javeriana, Cali, Colombia Jean-Marc Université ParisDauphine PSL IRD LEDa UMR [225] DIAL, Paris, France. Journal of Economic Integration. September 2017. 32(3):615-659

Altındal D, Akgün Ü 2007. Yeni Tohumculuk Yasası ve Türk Tarımına Etkileri SDÜ Ziraat Fakültesi Dergisi 2(2):27-35.

Bacchetta P, Van Wincoop E 2000. Does ExchangeRate Stability Increase Trade and Welfare? American Economic Review, 90 (5): 1093-1109.DOI: 10.1257/aer.90.5.1093

Baltagi Badi H 1995. Econometric analysis of panel data /ISBN 0-470-01456-3

Breitung J 2000. The local power of some unit root tests for panel data. In;Nonstation-ary Panels, Panel Cointegration, and Dynamic Panels, Baltagi, B.H. (Ed), Elsevier, Amsterdam, pp 161-177

Bergstrand Jeffrey H 1985. The gravity equation in international trade: Some microeconomic foundations and empirical evidence. Review of Economics and Statistics. 67:474-481.

Bergstrand Jeffrey H 1989. The generalized gravity equation, monopolistic competition, and the factorproportions theory in international trade. Review of Economics and Statistics. 71(1): 143-153

Breusch T and Pagan A 1979. A Simple Test for Heteroscedasticity and Random Coefficient Variation. Econometrica, 1979. 47(5):1287-1294

Cho G, Sheldon I, Mccorriston S 2002. American Journal of Agricultural Economics, 84(4):931-942. https://doi.org/10.1111/1467-8276.00044

Chowdhury AR 1993. Does Exchange Rate Volatility Depress Trade Flows? Evidence from ErrorCorrection Models. The Review of Economics and Statistics, 75(4):700-706

Disdier AC and Marette S 2010.The Combination Of Gravity And Welfare Approaches For Evaluating Nontariff Measures. Am. J. Agr. Econ. 92(3):713726.

Deardorff A 1998. Determinants of Bilateral Trade: Does Gravity Work in a Classical World? In: Frankel, J., Ed., The Regionalization of the World Economy, University of Chicago Press, Chicago. 
Elçi A 2000. Türkiye'de Tohumculuğun Durumu ve Değişimi. Türkiye Ziraat Mühendisleri V. Teknik Kongresi. 2: 859-870.

Gençtan T, Tugay ME, Geçit HH, Bozkurt B, Ergün E, Ekiz H, Yalvaç K, Gevrek MN, Elçi A, Balkan A 2007. Türkiye'de Tohumluk, Fide ve Fidan Üretimi ve Tüketimi. Türkiye Ziraat Mühendisleri VI. Teknik Kongresi. 803-823.

Gujaratı DN 2003. Basic Econometrics. New York: McGraw Hill Book Co.

Godfrey L 1978. Testing against General Autoregressive and Moving Average Error Models When the Regressors Include Lagged Dependent Variables. Econometrica, 46(6):1293-1301

Hilbun B, Keneddy P, and Dufour AE 2006. 'A Determination of the Trade Creation and Diversion Effects of Regional Trade Agreements in the Western Hemisphere'. Department of Agricultural Economics and Agribusiness 101 Ag. Administration Bldg. Louisiana State University, Ag Center Baton Rouge, LA 70893

Jarque CM, Bera AK 1980. Efficient tests for normality, homoscedasticity and serial independence of regression residuals, Economics Letters 6(3): 255-259

Kabir M and Salim R 2010. 'Can Gravity Model Explain BIMSTEC's Trade?'.Bangladesh Institute of International and Strategic Studies Curtin University of Technology. Journal of Economic Integration 25(1): 144-166

Kao WW, Karemera D and Taylor R 1994. 'A gravity model analysis of meat trade policies'. Agricultural Economics, 10(1):81-88.

Levin A, Lin CF 1992. "Unit Root Test in Panel Data: Asymptotic and Finite-Sample Properties", Discussion Paper, 92-93, Department of Economics,
University of California at San Diego (PDF) Panel Unit Root Tests: A Review. Available from: https://www.researchgate.net/publication/2527569 53_Panel_Unit_Root_Tests_A_Review [Accessed Aug 14 2018].

Levin A, Lin CF 1993. "Unit Root Test in Panel Data: New Results", Discussion Paper, 93-56, Department of Economics, University of California at San Diego. (PDF) Panel Unit Root Tests: A Review. Available from: https://www.researchgate. net/publication/252756953_Panel_Unit_Root_Tests _A_Review [Accessed Aug 14 2018].

Levin A, Lin CF, Chu CJ 2002. Unit root tests in panel data: asymptotic and finite sample properties. Journal of Econometrics 108(1):1-24.

Pedroni P 1999. Critical Values for Cointegration Tests in Heterogeneous Panels with Multiple Regressors. Oxford Bulletin of Economics and Statistics, 61(S1): 653-670.

Pezikoğlu F 2008. The EU CAP Reforms. Türktarım, May-June (181):34-37, Ankara.

Şahin A, Meral Y, Can M 2013. Türkiye Tohumculuk Sektörünün Analizi. Çankırı Karatekin Üniversitesi Sosyal Bilimler Enstitüsü Dergisi, 4(2): 73-88.

Yağdı K, Yılmaz K, Sezer N, Aydemir T, Bağcı SA 2010. Türkiye'de Tarla Bitkileri Tohumluk Üretimi ve Kullanımı ile Tohumculuk Sisteminin Genel Değerlendirmesi. Türkiye Ziraat Mühendisleri VII. Teknik Kongresi Erişim: http://www.zmo.org.tr /resimler/ekler/77ecc17109b1b80_ek.pdf

Yağdı K, Aydoğan EA, Kurt Polat PÖ 2015. Tarla Bitkileri Tohumluğu Üretimi ve Kullanımında Değişmeler ve Yeni Arayışlar. Türkiye Ziraat Mühendisleri VIII. Teknik Kongresi. 2:971-984. 